\title{
TATA-Box-Binding Protein
}

National Cancer Institute

\section{Source}

National Cancer Institute. TATA-Box-Binding Protein. NCI Thesaurus. Code C17578.

TATA-box-binding protein (339 aa, $~ 38 \mathrm{kDa}$ ) is encoded by the human TBP gene. This protein is involved in both DNA binding and gene transcription initiation. 